Check for updates

The BMJ

Cite this as: BMJ 2020;371:m4169 http://dx.doi.org/10.1136/bmj.m4169 Published: 28 October 2020

\section{Covid-19: UK deaths near 60000 as leaders call for realism about what NHS can handle}

\section{Elisabeth Mahase}

Covid-19-related deaths increased by more than $50 \%$ in the week ending 16 October, compared with the week before, according to the latest data from the Office for National Statistics (ONS). ${ }^{1}$

A total of 10534 deaths were registered in England and Wales over the seven day period, $6.8 \%$ above the five year average (669 deaths higher). Of these, 670 mentioned covid-19 (6.4\% of all deaths), an increase of 232 (53\%) compared with the previous week ( 438 deaths, $4.4 \%$ of all deaths). Across the UK, 58925 deaths relating to covid-19 have now been registered.

NHS Confederation director Layla McCay said, "These figures show how grave the situation has become, and how difficult the coming weeks and months are likely to be. Deaths have risen more than $50 \%$ in a week, marking the sixth weekly rise in a row, and we need action to curb this."

She said that providers of NHS care were reporting that their capacity is "severely stretched, and this is only likely to deteriorate over time as we see more covid-19 patients needing hospital treatment, alongside those with the usual winter illnesses." She raised concerns over the impact on routine services if staff need to be redeployed to covid-19 services, and called for "realism about what can be achieved, and understanding from both the government and the public."

The ONS figures also showed that while the total number of deaths reported in hospitals was lower than average for this period, with 184 fewer, there was an increase in the number of deaths in private homes and care homes (776 in total, 90 above average).

Nuffield Trust deputy director of research Sarah Scobie said, "The vulnerable social care sector is now becoming the epicentre of the covid-19 pandemic in this country. Despite a very small decrease in overall deaths from the previous week, the numbers in care homes are still growing.

"In the week to 24 April there were nearly four times more deaths registered in care homes than we would typically expect. We are now seeing almost as many deaths in care homes as hospitals which will be putting an incredible strain on overburdened care services."

Sheila Bird, former programme leader at the MRC Biostatistics Unit, University of Cambridge, said that while the rate of increase in this second wave of covid-19 is "currently lower and slower than in March 2020, when it was initially 10 fold," the virus is not going away.

"By changing our close contact patterns now, as Scotland's central belt did from 13 October for two weeks and Wales did, we need to moderate down the rate of increase over the coming weeks, and the sooner the better. But we shall also need to sustain reduced contact patterns for months, not just weeks, to see us through the winter. Serial circuit breakers can help us rein in exuberances," Bird said.

ONS. Deaths registered weekly in England and Wales, provisional: week ending 16 October 2020. 2020. www.ons.gov.uk/peoplepopulationandcommunity/birthsdeathsandmarriages/deaths/bulletins/deathsregisteredweeklyinenglandandwalesprovisional/weekending16october2020. 